\title{
URAN A THORIUM V GRANITICKÝCH PEGMATITECH A APLITECH SILEZIKA
}

\author{
Uranium and thorium in granitic pegmatites and aplites of Silesicum
}

\author{
Jiří Zimák \\ Katedra geologie PřF UP, tř. 17. listopadu 12, 77146 Olomouc; e-mail: zimak@prfnw.upol.cz
}

(14-22 Jeseník, 14-24 Bělá pod Pradědem, 14-41 Šumperk, 14-42 Rýmařov, 15-13 Vrbno pod Pradědem)

Key words: Silesicum, pegmatites, aplites, uranium, thorium, laboratory gamma-spectrometry

\begin{abstract}
Contents of uranium and thorium were measured using a laboratory gamma-ray spectrometer in 575 samples of granitic pegmatites and aplites from Silesicum. Very low contents of the both elements were found in metapegmatites occurring in metagranitoids and blastomylonites of the Desná Group, in pre-Variscan muscovite pegmatites with tourmaline, and in Variscan beryl-columbite pegmatites. Very high uranium and thorium contents are in some pegmatite dykes occurring on the Kluč Hill near Kociánov. The pegmatites are composed mainly of feldspars, quartz and mica (biotite and/or muscovite), and contain accessory minerals of uranium and thorium such as uraninite, coffinite and thorite. The Kluč Hill pegmatites are spatially and genetically bound to a small I-type Variscan granitoid body (so-called Rudná hora Intrusion). Highest average uranium contents were found in pyroxenic pegmatites occurring in the Žulová Massif mantle (its marbles can be considered the main source of uranium).
\end{abstract}

\section{Úvod}

V předložené zprávě jsou shrnuty poznatky o obsazích uranu a thoria v granitických pegmatitech a aplitech silezika. Z genetického a regionálně geologického hlediska lze studované horniny rozdělit do sedmi hlavních skupin, označovaných jako skupiny I až VII a stručně charakterizovaných v následujících odstavcích:

Skupina I: Metapegmatity $\mathrm{v}$ metagranitoidech a blastomylonitech desenské skupiny, zejména $\mathrm{v}$ její severní a střední části. Metapegmatity často mají povahu leukokrátních ortorul, výjimečně lze v nich pozorovat relikty blokového živce. Jde o pegmatity pravděpodobně kadomského stáŕí, metamorfované současně s okolními granitoidy. Lze je paralelizovat s pegmatity brunovistulika, známými z dyjsko-ivančického a slavkovského masivu i z ostrůvků krystalinika v Hornomoravském úvalu.

Skupina II: Poměrně primitivní muskovitické pegmatity s turmalínem, pravděpodobně prevariského stáŕí (viz Novák 2005), vystupující v horninách desenské skupiny (včetně skupiny Videlského potoka).

Skupina III: Beryl-columbitové pegmatity (charakterizované Novákem 2005) pronikající horninami sobotínského masivu (lokality Scheibengraben, Bienergraben, Schinderhübel a Lysá hora) a rulami keprnické skupiny (lokalita Dämmbaude u Branné).

Skupina IV: Aplity a texturně diferencované pegmatity prostorově a patrně i geneticky spjaté se šumperským masivem, vystupující v granitoidech tohoto masivu nebo v horninách jeho pláště (ruly a blastomylonity keprnické skupiny). Novák (2005) řadí pegmatity od Šumperka mezi beryl-columbitové, a to na základě prítomnosti berylu a columbitu v metasomatické jednotce pegmatitů na Ostředku (viz Procházka 1966).
Skupina V: Texturně diferencované pegmatity v rulách desenské skupiny v bezprostřední blízkosti granitoidní intruze Rudné hory (pegmatitové žily na svazích Kluče).

Skupina VI: Aplity a texturně diferencované pegmatity v horninách žulovského masivu, včetně pyroxenických pegmatitů $\mathrm{v}$ karbonátových horninách jeho pláště. Novák (2005) v rámci granitových pegmatitů žulovského plutonu vyčleňuje jako samostatné podtypy např. miarolitické pegmatity, diopsidové pegmatity, allanitové pegmatity a gadolinitové pegmatity.

Skupina VII: Pegmatoidní granity a texturně slabě diferencované pegmatity vystupující u České Vsi (Čertovy kameny a Bělák) a Písečné.

Většinu aplitových žil a pegmatitových těles $v$ prostoru silezika lze přiřadit $\mathrm{k}$ jedné ze sedmi výše uvedených skupin. Př́kladem do tohoto systému nezařaditelných pegmatitů mohou být pegmatitové žíly vystupující v lomu $\mathrm{v}$ Bukovicích (a zmiňované v této zprávě). Problémy mohou nastat při rozlišování mezi skupinami I a II, a to zejména $v$ př́padech, kdy je pegmatit $v$ terénu nalezen jen $\mathrm{v}$ podobě drobných fragmentů.

\section{Vzorky a metody}

K výzkumu byl využit soubor 575 vzorků aplitů a granitových pegmatitů z území silezika, odebraných autorem této zprávy během terénních prací realizovaných v posledních cca 30 letech. V souboru vzorků jsou zastoupeny všechny lokality významné z hlediska výskytu aplitů a pegmatitů. $\mathrm{V}$ př́padě texturně diferencovaných pegmatitových těles byly odebírány reprezentativní vzorky z jednotlivých jednotek. Jako aplopegmatity jsou označovány bud' samostatné žíly zrnitostně na rozhraní mezi aplitem a pegmatitem (ty jsou typické pro žulovský masiv), nebo je tento termín užíván k označení horninových partií na přechodu mezi aplitickou jednotkou a jednotkou charakteru 
středně zrnitého pegmatitu (příp. i grafického pegmatitu).

Pomocí laboratorního gamaspektrometru SG - 1000 LAB s $\mathrm{NaI}(\mathrm{Tl})$ detektorem o objemu $0,35 \mathrm{dm}^{3}$ (průměr $76 \mathrm{~mm}$, délka $76 \mathrm{~mm}$ ) byly ve vzorcích stanoveny obsahy uranu a thoria, mez detekce pro oba prvky je shodně 1,5 ppm. Při statistickém zpracování dat byly obsahy U a Th pod mezí detekce nahrazeny hodnotou 1 ppm. Před měřením byly horninové vzorky rozdrceny a uzavřeny do krabiček o objemu $250 \mathrm{ml}$, v nichž byly následně měřeny. Hmotnost takto připravených vzorků se pohybovala kolem 400 gramů. Některé vzorky byla měřeny v původním stavu, tedy neměly pro měření ideální geometrii (hmotnost jednotlivých vzorků se pohybovala $v$ rozpětí 300 až 900 gramů). Výsledky těchto měření proto mohou být zatíženy určitou chybou, která však není zásadně významná.

V souboru vzorků reprezentujících určitou texturní jednotku konkrétního pegmatitového tělesa lze někdy zjistit velmi široké rozpětí obsahů uranu a thoria, což souvisí s nerovnoměrnou distribucí nositelů obou prvků v rámci této jednotky. Je nutno poznamenat, že vzhledem ke značným rozměrům zrn v některých jednotkách či partiích pegmatitových těles by hmotnost reprezentativních vzorků měla být $\mathrm{v}$ řádu desítek kilogramů, případně i větší. $Z$ tohoto dủvodu byl z jednotlivých pegmatitů a jejich jednotek analyzován relativně velký počet vzorků, aby průměrné hodnoty bylo možno považovat za reprezentativní. Na lokalitách, v jejichž vzorcích byl v počáteční etapě výzkumu zjištěn relativně vysoký obsah uranu nebo thoria (např. lom v Bukovicích a kopec Kluč), byl proveden odběr dalšího materiálu, a soubory vzorků $\mathrm{z}$ těchto lokalit tak byly výrazně rozšířeny.
Tab. 1: Obsahy uranu a thoria v metapegmatitech a primitivních pegmatitech s turmalínem $\mathrm{v}$ desenské skupině, $\mathrm{v}$ aplitech a pegmatitech šumperského masivu a jeho pláště, $\mathrm{v}$ pegmatitech u Velkých Losin a Rapotína, na kopci Kluč, u České Vsi a Písečné a v lomu Bukovice $(\mathrm{MP}=$ metapegmatity, $\mathrm{T}$ = primitivní pegmatity s turmalínem, $\mathrm{A}=$ aplity a aplopegmatity, $\mathrm{P}=$ pegmatity, $\mathrm{n}=$ počet vzorků).

Tab. 1: Uranium and thorium contents in metapegmatites and primitive pegmatites with tourmaline in the Desná Group, in aplites and pegmatites of the Šumperk Massif and its mantle, in pegmatites at Velké Losiny and Rapotín, on the Kluč Hill, at Česká Ves and Písečná, and in the Bukovice Quarry $(\mathrm{MP}=$ metapegmatites, $\mathrm{T}=$ primitive pegmatites with tourmaline, $\mathrm{A}=$ aplites and aplopegmatites, $\mathrm{P}=$ pegmatites, $\mathrm{n}=$ number of samples).

\begin{tabular}{|c|c|c|c|c|c|c|c|c|c|c|}
\hline \multirow{2}{*}{ oblast / horninový typ } & \multirow{2}{*}{ sk. } & \multirow{2}{*}{$\mathrm{n}$} & \multicolumn{4}{|c|}{$\mathrm{eU}(\mathrm{ppm})$} & \multicolumn{4}{|c|}{ eTh (ppm) } \\
\hline & & & min. & $\max$. & med. & $\mathrm{x}$ & $\min$. & $\max$. & med. & $\mathrm{x}$ \\
\hline desenská skupina/MP & I & 21 & $<1,5$ & 1,9 & $<1,5$ & $<1,5$ & $<1,5$ & 9,6 & $<1,5$ & 2,0 \\
\hline desenská skupina/T & II & 51 & $<1,5$ & 11,1 & $<1,5$ & 1,7 & $<1,5$ & 5,9 & $<1,5$ & $<1,5$ \\
\hline Domašov („,V kotli“)/T & II & 16 & $<1,5$ & 21,4 & 2,8 & 4,7 & $<1,5$ & 2,5 & $<1,5$ & $<1,5$ \\
\hline šumperský masiv/P & IV & 4 & 1,5 & 2,7 & 1,9 & 2,0 & 11,4 & 13,5 & 13,0 & 12,8 \\
\hline pláśt’ šumperského masivu/P & IV & 67 & $<1,5$ & 5,7 & 2,1 & 2,2 & $<1,5$ & 12,6 & 4,5 & 4,8 \\
\hline plášt šumperského masivu/A & IV & 2 & 5,8 & 8,3 & 7,0 & 7,0 & 8,2 & 8,7 & 8,4 & 8,4 \\
\hline Velké Losiny, Rapotín/P & IV & 44 & $<1,5$ & 10,3 & 1,9 & 2,6 & $<1,5$ & 19,3 & 2,9 & 3,8 \\
\hline Kluč - hlavní žíla/P & $\mathrm{V}$ & 33 & $<1,5$ & 11,1 & 2,5 & 3,3 & $<1,5$ & 14,7 & 4,5 & 4,9 \\
\hline Kluč - ostatní výskyty/P & $\mathrm{V}$ & 38 & $<1,5$ & 105,5 & 7,2 & 18,5 & $<1,5$ & 99,0 & 10,2 & 19,9 \\
\hline Česká Ves, Písečná/P & VII & 13 & $<1,5$ & 5,3 & 2,5 & 2,6 & 2,9 & 13,1 & 4,1 & 5,2 \\
\hline Bukovice/P & & 24 & 1,6 & 22,7 & 4,5 & 5,5 & 1,9 & 21,3 & 8,3 & 8,9 \\
\hline Bukovice/A & & 2 & $<1,5$ & 6,4 & 3,7 & 3,7 & 10,7 & 19,6 & 15,2 & 15,2 \\
\hline
\end{tabular}

Tab. 2: Obsahy uranu a thoria v beryl-columbitových pegmatech ( $\mathrm{n}=$ počet vzorků).

Tab. 2: Uranium and thorium contents in beryl-columbite pegmatites ( $\mathrm{n}=$ number of samples).

\begin{tabular}{|c|c|c|c|c|c|c|c|c|c|c|}
\hline & \multirow{2}{*}{ sk. } & \multirow{2}{*}{$\mathrm{n}$} & \multicolumn{4}{|c|}{$\mathrm{eU}(\mathrm{ppm})$} & \multicolumn{4}{|c|}{ eTh (ppm) } \\
\hline & & & $\min$. & $\max$. & med. & $\mathrm{x}$ & $\min$. & $\max$. & med. & $\mathrm{x}$ \\
\hline Sobotín - Bienergraben & III & 14 & $<1,5$ & 5,7 & $<1,5$ & 1,5 & $<1,5$ & 8,1 & $<1,5$ & 2,1 \\
\hline Maršíkov - Lysá hora & III & 29 & $<1,5$ & 15,6 & 2,8 & 4,2 & $<1,5$ & 13,4 & 4,1 & 4,7 \\
\hline Schinderhübel - žíla I & III & 13 & 1,8 & 10,7 & 4,2 & 4,9 & 2,1 & 5,9 & 3,0 & 3,2 \\
\hline Schinderhübel - žíla II & III & 6 & $<1,5$ & $<1,5$ & $<1,5$ & $<1,5$ & $<1,5$ & 2,7 & $<1,5$ & $<1,5$ \\
\hline Schinderhübel - žíla III & III & 9 & $<1,5$ & 5,8 & 3,6 & 3,3 & 1,6 & 5,9 & 3,8 & 3,8 \\
\hline Scheibengraben/grafická jednotka & III & 11 & $<1,5$ & $<1,5$ & $<1,5$ & $<1,5$ & $<1,5$ & 6,5 & $<1,5$ & 1,5 \\
\hline Scheibengraben/hrubě zrnitá jednotka & III & 13 & $<1,5$ & $<1,5$ & $<1,5$ & $<1,5$ & $<1,5$ & 5,7 & 2,0 & 2,3 \\
\hline Scheibengraben/bloková jednotka & III & 5 & $<1,5$ & $<1,5$ & $<1,5$ & $<1,5$ & $<1,5$ & $<1,5$ & $<1,5$ & $<1,5$ \\
\hline $\begin{array}{l}\text { Scheibengraben/metasomatická } \\
\text { jednotka }\end{array}$ & III & 16 & $<1,5$ & 5,4 & 1,5 & 2,0 & 3,2 & 23,3 & 8,4 & 10,2 \\
\hline Dämmbaude/hrubě zrnitá jednotka & III & 8 & $<1,5$ & 2,8 & 1,2 & 1,6 & $<1,5$ & 2,9 & 1,6 & 1,6 \\
\hline Dämmbaude/bloková jednotka & III & 8 & $<1,5$ & 4,3 & 2,4 & 2,4 & $<1,5$ & 1,9 & 1,6 & 1,5 \\
\hline Dämmbaude/metasomatická jednotka & III & 12 & $<1,5$ & 6,9 & 1,8 & 2,2 & $<1,5$ & 7,6 & 1,3 & 2,1 \\
\hline
\end{tabular}

Tab. 3: Obsahy uranu a thoria $v$ aplitech a pegmatitech žulovského masivu a jeho pláště $(A=$ aplity a aplopegmatity, $\mathrm{P}=$ pegmatity, $\mathrm{n}=$ počet vzorků).

Tab. 3: Uranium and thorium contents in aplites and pegmatites of the Žulová Massif and its mantle ( $\mathrm{A}=$ aplites and aplopegmatites, $\mathrm{P}=$ pegmatites, $\mathrm{n}=$ number of samples $)$.

\begin{tabular}{|c|c|c|c|c|c|c|c|c|c|c|}
\hline & \multirow{2}{*}{ sk. } & \multirow{2}{*}{$\mathrm{n}$} & \multicolumn{4}{|c|}{$\mathrm{eU}(\mathrm{ppm})$} & \multicolumn{4}{|c|}{ eTh (ppm) } \\
\hline & & & $\min$. & $\max$. & med. & $\mathrm{x}$ & $\min$. & $\max$. & med. & $\mathrm{x}$ \\
\hline Žulová, Černá Voda/A & VI & 30 & 1,7 & 8,2 & 3,2 & 3,7 & 2,7 & 15,4 & 6,2 & 7,0 \\
\hline $\begin{array}{l}\text { Žulová, Vápenná, Černá Voda, } \\
\text { N. Č. Voda/P }\end{array}$ & VI & 45 & $<1,5$ & 17,1 & 1,9 & 3,3 & $<1,5$ & 66,7 & 6,2 & 9,0 \\
\hline Dolní Skorošice/A & VI & 10 & $<1,5$ & 9,0 & 3,7 & 4,3 & 5,2 & 35,9 & 18,4 & 21,2 \\
\hline Dolní Skorošice/P & VI & 6 & $<1,5$ & 4,2 & 2,3 & 2,5 & 4,7 & 12,6 & 8,1 & 8,4 \\
\hline Velká Kraš/P & VI & 12 & $<1,5$ & $<1,5$ & $<1,5$ & $<1,5$ & $<1,5$ & 1,9 & $<1,5$ & $<1,5$ \\
\hline Supíkovice/P & VI & 3 & 9,5 & 12,3 & 10,1 & 10,6 & 4,7 & 9,3 & 5,3 & 6,4 \\
\hline Žulová/allanitový P & VI & 10 & 3,4 & 15,0 & 6,0 & 6,9 & 4,9 & 18,0 & 7,0 & 8,4 \\
\hline
\end{tabular}




\section{Výsledky a diskuze}

Výsledky všech provedených gamaspektrometrických měření jsou sumarizovány v tabulkách 1 až 3 . Hlavní poznatky jsou shrnuty a stručně komentovány $\mathrm{v}$ následujících odstavcích:

1. V rámci studovaného souboru hornin vykazují nejnižší obsahy uranu a thoria metapegmatity desenské skupiny (pegmatity skupiny I), jejichž vzorky byly odebrány na katastrálních územích Horní Údolí, Seč u Rejvízu, Ludvíkov, Andělská Hora, Domašov, Vernírovice, Rudoltice, Hrabišín a Mladoňov. Obsahy obou prvků jsou většinou pod 1,5 ppm (tab. 1). Nízkými obsahy uranu se metapegmatity desenské skupiny podobají metagranitoidům a blastomylonitům této skupiny a také pegmatitům brunovistulika vystupujícího v Hornomoravském úvalu, slavkovském masivu a dyjsko-ivančickém masivu (viz Zimák 2011).

2. Velmi nízké obsahy uranu a thoria vykazují i primitivní muskovitické pegmatity s turmalínem (skupina II). Soubor celkem 67 vzorků je v tabulce 1 rozdělen do dvou částí. První $(\mathrm{n}=51)$ reprezentuje typické pegmatity této skupiny (charakterizované Novákem 2005), vystupující v metagranitoidech a blastomylonitech desenské skupiny (Rejvíz, Domašov), v tzv. desenských rulách (Rejhotice, Kociánov) a hojně v metaprachovcích a metaarkózách skupiny Videlského potoka (Horní Údolí, Železná, Malá Morávka). Do druhé byly zařazeny pegmatity z prostoru lokality zvané „V kotli“ (Čech 1963, Kruta 1973), jejichž vzorky byly odebrány cca $450 \mathrm{~m}$ zsz. od kóty $981 \mathrm{~m}$ (Hřib) v k. ú. Domašov. Výchoz či výchozy pegmatitů zde nejsou známy, pegmatit se zde vyskytuje $\mathrm{v}$ podobě balvanů a menších fragmentů $\mathrm{v}$ deluviu. Vedle křemene, živce (převažuje plagioklas, to dokládají i gamaspektrometricky stanovené obsahy draslíku) a muskovitu je zde relativně hojný turmalín (černé sloupcovité krystaly o délce až $12 \mathrm{~cm}$ ) a také granát. Jak uvádí již Čech (1963), pegmatit je tlakově značně postižen, což je zřejmé i z rozlámání turmalínových krystalů. Od typických primitivních muskovitických pegmatitů s turmalínem se liší relativně hojným granátem a zejména prítomností tantaloniobátů, zde nalezených Čechem (1963), jenž v jejich agregátu určil mikrolit (resp. „uran-mikrolit“). V gamaspektrometricky analyzovaném souboru vzorků z lokality „V kotli“ byly zastoupeny i dva vzorky pegmatitu s drobnými černohnědými agregáty, tvořenými pravděpodobně tantaloniobáty. V obou vzorcích byly stanoveny relativně vysoké obsahy uranu (15,4 a 21,4 ppm e U), patrně vázané na př́tomnost tantaloniobátů.

3. Pegmatity skupiny IV v granitoidech šumperského masivu (Bludov) vykazují obsahy uranu a thoria blízké klarkovým hodnotám (tab. 1). Velmi podobné průměrné obsahy uranu a výrazně nižší obsahy thoria mají pegmatity v plášti šumperského masivu v jeho bezprostřední blízkosti (Šumperk, Horní Temenice, Bratrušov, Osikov a Rapotín) a také na lokalitách od výchozů šumperského masivu více vzdálených (Velké Losiny a Rapotín - jde o lokality na Lázeňském vrchu a zejména $\mathrm{v}$ prostoru kót Bukový kopec a Strážník). Relativně vysoký průměrný obsah uranu $(7,0$ ppm eU) byl zjištěn v aplitu z lomu na Ostředku. Nutno

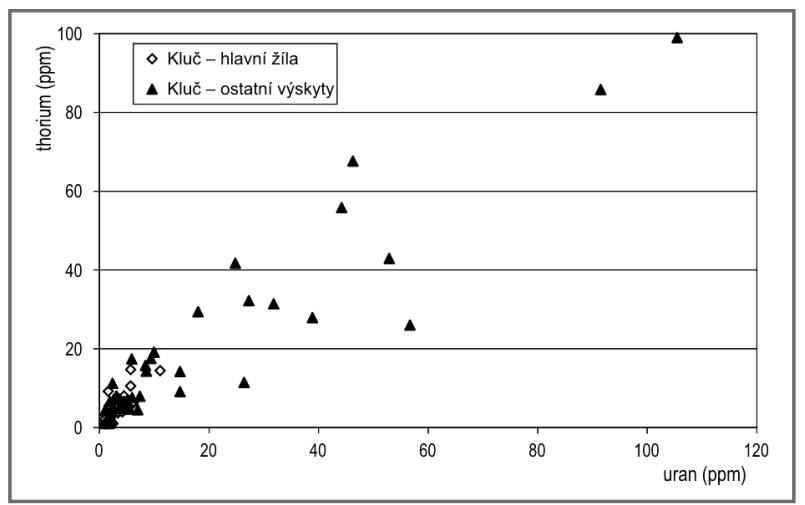

Obr. 1: Korelace uran versus thorium v pegmatitech na kopci Kluč u Kociánova.

Fig. 1: Uranium versus thorium correlation in pegmatites on the Kluč Hill near Kociánov.

poznamenat, že z aplopegmatitů na Ostředku a blízkých Městských skalách je Procházkou $(1966,1969)$ uváděna př́tomnost uranových slíd - autunitu a také torbernitu (?).

4. Z hlediska obsahů uranu a thoria jsou zajímavé pegmatity na západním svahu Kluče (skupina V), mineralogicky zhodnocené Vachovou (2012). Hlavní žíla vystupující v několika výchozech $\mathrm{v}$ délce $c c a 350 \mathrm{~m}$ při hranici k. ú. Maršíkov a Filipová (střed žíly je cca $1400 \mathrm{~m}$ jz. od kóty 892,4 Kluč) má jen relativně nízké průměrné obsahy U a Th (tab. 1). V žádném z ní odebraných vzorků (celkem 33) nebyly stanoveny výrazně vysoké obsahy sledovaných prvků (viz obr. 1). Kromě materiálu z hlavní žily byly studovány vzorky pegmatitů z dalších devíti lokalit na západním svahu Kluče - data jsou sumarizována v tabulce 1 v položce „ostatní výskyty“, obsahy uranu a thoria $v$ jednotlivých vzorcích jsou vyjádřeny $v$ obrázku 1. Na dvou z těchto lokalit (obě jsou na k. ú. Kociánov) byly zjištěny extrémně vysoké obsahy uranu a thoria. Na první z nich (cca $380 \mathrm{~m}$ západně od kóty $892,4 \mathrm{~m}$ ) bylo v hrubozrnném křemen-živec-biotitovém pegmatitu stanoveno až 105,5 ppm eU a 99,0 ppm eTh, v křemen-živec-muskovitovém až 46,3 ppm eU a 67,6 ppm eTh. Na druhé z lokalit (cca $900 \mathrm{~m}$ ssz. od kóty $892,4 \mathrm{~m}$ ) byly ve dvou zde odebraných vzorcích pegmatoidního granitu zjištěny obsahy 56,7 a 52,9 ppm eU a 26,0 a 42,9 ppm eTh. Zvýšené obsahy obou prvkủ souvisí s přítomností urani-

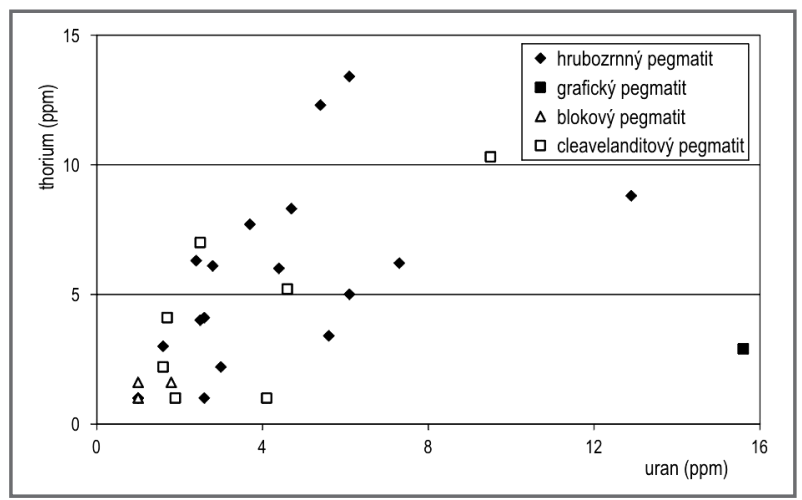

Obr. 2: Korelace uran versus thorium v pegmatitech na Lysé hoře. Fig. 2: Uranium versus thorium correlation in pegmatites on the Lysá hora. 
nitu, coffinitu, thoritu, xenotimu-(Y), zirkonu, monazitu-(Ce) a blíže neurčeného tantaloniobátu s podstatným obsahem U a Th (Vachová 2012 a nepublikovaná data autora). Pozitivní korelace mezi uranem a thoriem je zřejmá z obrázku 1. Pegmatity na Kluči jsou prostorově a patrně i geneticky spjaty s variskou granitoidní intruzí Rudné hory, složenou hlavně z alkalicko-živcového granitu a syenogranitu s druhově bohatou asociací akcesorií, jejíž součástí jsou i minerály obsahující uran a thorium - např. zirkon, monazit-(Ce), xenotim-(Y), euxenit-(Y), allanit(Ce) a cheralit (Nejeschlebová et al. 2012).

5. Obsahy uranu a thoria v beryl-columbitových pegmatitech (skupina III) jsou uvedeny v tabulce 2. Zvýšené obsahy obou prvků byly zjištěny jen v některých vzorcích z pegmatitu na Lysé hoře (tab. 2, obr. 2) a lze je spojovat s př́tomností uraninitu, coffinitu, cheralitu, aeschynitu-(Ce), yttrobetafitu-(Y), samarskitu-(Y) a př́padně dalších tantaloniobátů (viz Chládek 2011, Chládek a Zimák 2012). V prostoru lokality Schinderhübel byly studovány vzorky ze tří pegmatitových žil (označení žil v tabulce 2 je podle Černého et al. 1992 a Nováka 2002) - překvapením jsou velmi nízké obsahy uranu a thoria na žíle II (jde o žílu cca 30 m východně od klasického naleziště chryzoberylu). Pokud byly na lokalitě Schinderhübel zjištěny relativně vysoké obsahy U a Th, šlo vždy o vzorky, v nichž byl ve větší míre přítomen cukrový albit. $V$ rámci pegmatitového tělesa na lokalitě Scheibengraben byly zvýšené obsahy obou prvků stanoveny pouze $\mathrm{v}$ několika vzorcích $\mathrm{z}$ metasomatické jednotky (cukrového albitu), jejich nositelem jsou zde patrně tantaloniobáty. Na lokalitě Dämmbaude nebyly z hlediska průměrných obsahů $U$ a Th zjištěny žádné výraznější rozdíly mezi jednotlivými jednotkami (viz tab. 2), ale i v prípadě tohoto pegmatitového tělesa lze konstatovat, že vzorky s nejvyššími obsahy U a Th pocházejí z metasomatické jednotky tvořené hlavně cukrovým albitem.

6. Pegmatity a aplity ze žulovského masivu a jeho pláště (skupina VI) jsou rozděleny do sedmi podskupin (viz tab. 3). První dvě podskupiny zahrnují celkem 75 vzorků reprezentujících žíly aplitů a pegmatitů v granitech žulovského masivu na k. ú. Žulová, Vápenná, Černá Voda a Nová Červená Voda (vzorky z aplitické jednotky byly $\mathrm{v}$ těchto prrípadech zařazeny mezi aplity). Pokud jde o průměrné obsahy uranu a thoria, neexistuje mezi oběma podskupinami hornin žádný výraznější rozdíl. Větší pegmatitová tělesa ve zmíněné oblasti jsou často výrazně texturně diferencována - ve směru od okraje do centra lze v jejich typických reprezentantech rozlišit: (i) jednotku aplitu (resp. aplopegmatitu), (ii) hrubě zrnitou jednotku tvořenou K-živcem, křemenem a biotitem a (iii) blokovou jednotku. I když jsou obsahy U a Th v souboru vzorků z hrubě zrnité jednotky velmi variabilní (to je způsobeno malými rozměry vzorků ve vztahu k jejich zrnitosti), průměrné obsahy U a Th v aplitické a hrubě zrnité jednotce jsou velmi podobné. V blokové jednotce bývají obsahy obou sledovaných prvků nižší. Extrémním příkladem je pegmatitové těleso ve Velké Kraši (viz Novák et al. 2000), z jehož mohutně vyvinuté blokové jednotky bylo odebráno 12 vzorků, v nichž jsou obsahy uranu a thoria většinou pod 1,5 ppm (tab. 3). Jako samostatné položky jsou v tabulce 3

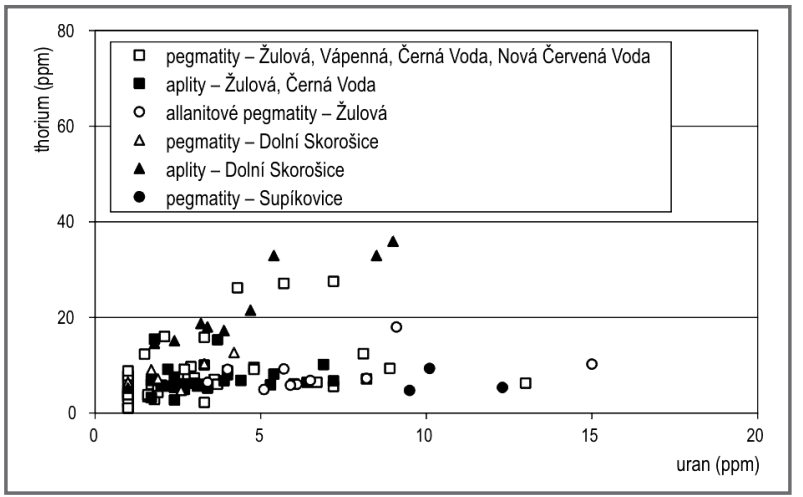

Obr. 3: Korelace uran versus thorium v pegmatitech a aplitech žulovského masivu a jeho pláště.

Fig. 3: Uranium versus thorium correlation in pegmatites and aplitech of the Žulová Massif and its mantle.

uvedeny aplity a pegmatity z k. ú. Dolní Skorošice (z lomů na Kaní hoře), které reprezentují žilné horniny pronikající starší (bazičtější) částí žulovského masivu (dioritoidy, převážně křemenný monzodiorit). Pro aplity a aplopegmatity z Dolních Skorošic jsou charakteristické relativně vysoké obsahy thoria (v průměru 21,2 ppm Th). Zajímavé jsou zvýšené obsahy uranu $\mathrm{v}$ pegmatitech pronikajících mramory v plášti žulovského masivu. Ve studovaném souboru vzorků jsou reprezentovány pyroxenickými pegmatity (či pyroxenickými pegmatoidy - viz Žáček 1997) ze Supíkovic (průměr 10,6 ppm eU) a pyroxenickými pegmatity s titanitem a allanitem-(Ce) z Jaškova lomu u Žulové (průměr 6,9 ppm eU). Zdrojem zvýšených obsahů uranu v pyroxenických pegmatitech jsou patrně okolní karbonátové horniny. Na obrázku 3 jsou znázorněny výsledky všech stanovení uranu a thoria $\mathrm{v}$ jednotlivých vzorcích ze skupiny VI, s výjimkou souboru vzorků z Velké Kraše.

7. Pegmatity a pegmatoidní granity z České Vsi a Písečné (skupina VII) se obsahy uranu a thoria velmi podobají (pokud jde o median - viz tab. 1) pegmatitům $\mathrm{v}$ granitoidech žulovského masivu (tab. 3, lokality na k. ú. Žulová, Vápenná, Černá Voda, Nová Červená Voda). To ukazuje na genetické sepětí hornin skupiny VII s žulovským masivem.

\section{Závěry}

1. V prostoru silezika mají nejnižší obsahy uranu a thoria metapegmatity $\mathrm{v}$ metagranitoidech a blastromylonitech desenské skupiny a primitivní muskovitické pegmatity s turmalínem $\mathrm{v}$ těchže horninách a také $\mathrm{v}$ metaprachovcích a metaarkózách skupiny Videlského potoka a v tzv. desenských rulách. Výjimkou jsou muskovitické pegmatity s turmalínem z lokality „V kotli“ ( $\mathrm{k}$. ú. Domašov) se zvýšenými obsahy uranu (až 21,4 ppm eU), vázanými patrně na tantaloniobáty.

2. Beryl-columbitové pegmatity mají jen nízké obsahy uranu a thoria. V př́padě lokality Scheibengraben bylo zjištěno mírné zvýšení obsahu thoria $\mathrm{v}$ metasomatické jednotce.

3. Extrémně vysoké koncentrace uranu a thoria (až 46,3 ppm eU a 67,6 ppm eTh) byly zjištěny v pegmatitech na z. svahu Kluče (k. ú. Kociánov). Vysoké obsahy 
obou prvků souvisí s př́tomností uraninitu, coffinitu, thoritu a také několika dalších minerálů, obsahujících U a Th jako príměs. Pegmatity na Kluči jsou geneticky patrně spjaty s variskou granitoidní intruzí Rudné hory.

4. Aplity v lomu na Ostředku u Šumperka mají v průměru 7,0 ppm eU. Př́tomnost uranových minerálů na této lokalitě byla již dříve známa (U-slídy uváděné Procházkou 1966, 1969).

5. V žulovském masivu mají aplity v dioritoidech výrazně vyšší obsahy thoria (v průměru 21,2ppm eTh) než aplity $\mathrm{v}$ granitoidech (v průměru 7,0 ppm eTh).
6. V texturně diferencovaných granitických pegmatitech žulovského masivu byly nejnižší obsahy uranu a thoria stanoveny v blokové zóně a křemenném jádru.

7. V rámci žulovského masivu a jeho pláště byly nejvyšší obsahy uranu zjištěny v pyroxenických pegmatitech (pegmatitoidech) pronikajících mramory (v průměru až 10,6 ppm eU). Zdrojem uranu byly patrně okolní karbonátové horniny.

Literatura

Čech, F. (1963): Př́́spěvky k mineralogii Moravy a Slezska. - Časopis Moravského musea, Vědy př́rodní, 48, 31-42.

Černý, P. - Novák, M. - Chapman, R. (1992): Effects of sillimanite-grade metamorphism and shearing on Nb,Ta-oxide minerals in granitic pegmatites: Maršíkov, northern Moravia, Czechoslovakia. - Canadian Mineralogist, 30, 699-718.

Chládek, Š. (2011): Mineralogická charakteristika pegmatitu na Lysé hoře u Maršíkova v Hrubém Jeseníku. - MS, bakalářská práce. Př́rodovědecká fakulta Univerzity Palackého. Olomouc.

Chládek, Š. - Zimák, J. (2012): Unikátní nález berylu v pegmatitu na Lysé hoře u Maršíkova. - Minerál, 20, 488-494.

Kruta, T. (1973): Slezské nerosty a jejich literatura. Moravské muzeum v Brně.

Nejeschlebová, L. - Zimák, J. - René, M. (2012): Granitoidy intruze Rudné hory v Hrubém Jeseníku a jejich akcesorie. - Zprávy Vlastivědného muzea v Olomouci, No. 303, 113-117.

Novák, M. (2002): Lokalita č. 9. Maršíkov - Schinderhübel. - In: Zimák J. et al.: Exkurzní průvodce po mineralogických lokalitách na Sobotínsku, 34-37. Univerzita Palackého v Olomouci.

Novák, M. (2005): Granitické pegmatity Českého masivu (Česká republika): mineralogická, geochemická a regionální klasifikace a geologický význam. - Acta Musei Moraviae, Scientiae geologicae, 90, 3-74.

Novák, M. - Kimbrough, D. L. - Taylor, M. C. - Černý, P. (2000): Radiometrické U/Pb stáří monazitu z granitického pegmatitu u Velké Kraše, žulovský pluton. - Moravskoslezské paleozoikum 2000, s. 13. Brno.

Procházka, J. (1966): O nových pegmatitech a jejich minerálech z okolí Šumperka. - Časopis Moravského musea, Vědy přírodní, $51,43-60$.

Procházka, J. (1969): Autunit, bertrandit a bismutit z pegmatitů od Šumperka. - Časopis Moravského musea, Vědy př́írodní, 54, 31-44.

Vachová, S. (2012): Mineralogie pegmatitů na Kluči u Filipové v Hrubém Jeseníku. - MS, diplomová práce, Přírodovědecká fakulta Univerzity Palackého. Olomouc.

Zimák, J. (2011): Přirozená radioaktivita granitoidů a metagranitoidů brunovistulického teránu na území České republiky. Geologické výzkumy na Moravě a ve Slezsku, 18, 201-204.

Žáček, V. (1997): Metasomatické žíly pyroxenického pegmatoidu z pláště žulovského granitového plutonu. - Geologické výzkumy na Moravě a ve Slezsku v roce 1996, 111-114. 